\title{
Efektivitas Larvasida Formula Granul Mengandung Ekstrak Bunga Melati (Jasminum sambac) dan Biji Pepaya (Carica papaya L.) Terhadap Mortalitas Larva Aedes aegypti
}

\author{
Jevi Ramadhan Berliani, Yumna Zulfa Salsabila, Rindy Fidestia Anjaini dan Heru \\ Sasongko* \\ Program Studi D3 Farmasi, Sekolah Vokasi, Universitas Sebelas Maret, Jl. Ir. Sutami 36A, Surakarta, Indonesia, \\ 57126 \\ *email korespondensi : heru_sasongko@staff.uns.ac.id \\ Received 16 June 2019, Accepted 29 September 2020, Published 15 March 2021
}

\begin{abstract}
Abstrak: Nyamuk Aedes aegypti merupakan vector utama pada kejadian demam berdarah (DBD). Pencegahan penularan DBD menggunakan bahan kimia disinyalir menimbulkan permasalahan sendiri diataranya adalah pencemaran lingkungan, resisten dan residu bahan kimia. Penelitian ini bertujuan untuk mengetahui efektivitas formula granul yang mengandung ekstrak bunga melati (EBM) dan ekstrak biji papaya (EBP) terhadap mortalitas larva nyamuk Aedes aegypti. Ekstrak diperoleh menggunakan metode maserasi. Formula dibuat menggunakan metode granulasi basah. Uji larvasida menggunakan 30 larva yang terbagi dalam 6 kelompok yaitu kelompok kontrol dan formula. Kelompok kontrol terdiri dari kontrol negatif yaitu formula granul tanpa zat aktif dan kelompok pemberian serbuk abate sebagai kontrol positif. Kelompok formula terdiri dari formula mengandung EBM 10\%, EBP 10\%, formula kombinasi mengandung EBM dan EBP (5\%:5\%) dan (10\%:10\%). Nilai persen mortalitas larva diamati setelah 24 jam pemberian formula granul. Uji statistik one wayANOVA dilanjutkan Post-Hoc Test LSD dilakukan untuk melihat perbedaan antar kelompok. Hasil penelitian menunjukkan bahwa formula mengandung ekstrak tunggal EBP memberikan nilai persen mortalitas secara signifikan $(\mathrm{p}<0.05)$ dengan nilai $60 \%$. Pada formula kombinasi EBM dan EBP (5\%:5\% dan 10\%:10\%) memberikan nilai persen mortalitas sebesar 13,4\% dan $26,6 \%$ berbeda signifikan dibandingkan dengan kontrol negatif $(\mathrm{p}<0.05)$.
\end{abstract}

Kata kunci: Aedes aegypti; larvasida; biji papaya; bunga melati

\begin{abstract}
Larvicide Effect of Granule Formula Containing Jasmine Flower (Jasminum sambac) and Papaya Seeds (Carica papaya L.) Extract Against Mortality of Aedes aegypti Larvae. Aedes aegypti is the main vector for dengue fever (DHF). The Prevention of dengue transmission using chemicals causes its own problems, including environmental pollution, resistance and chemical residues. This study aimed to determine the effectiveness of granule formulation containing jasmine flower extract and papaya seed extract on the mortality of Aedes aegypti mosquito larvae. The extract was obtained using the maceration method, and the formula was produced using wet granulation method. The larvicidal test used 30 larvae, which were divided into six groups there were controls group and formula groups. Control group was formula without active substance as a negative control, and it was given abate powder as the positive control. Formula groups were divided into $10 \%$ jasmine flower extract, $10 \%$ papaya seed extract, the combination of both extract (5\%:5\%), and (10\%:10\%). Percent mortality value of larvae was observed after 24 hours of granule formula application. Statistical test using one way-ANOVA to determine the differences between groups. The significant difference between groups was continued with the LSD Post Hoc Test. The results showed that the formula containing a single extract of papaya seed extract gave a significant percentage of mortality $(p<0.05)$ with a value of $60 \%$. In the combination formula extract
\end{abstract}


(5\%: $5 \%$ and 10\%: 10\%), the percentage value of mortality was $13.4 \%$ and $26.6 \%$, which differed significantly compared to the negative control ( $\mathrm{p}<0.05)$.

Keywords: Aedes aegypti; larvicidal; Carica papaya; Jasminum sambac

\section{Pendahuluan}

Demam Berdarah Dengue (DBD) adalah kasus endemik yang sering terjadi di negara beriklim tropis seperti Indonesia. Kasus dengue didunia terjadi setiap tahun dengan angka estimasi 390 juta kasus, 96 juta diantaranya termanifestasi secara klinis (dengan keparahan penyakit yang berbeda) (Ikawati, 2018). Kejadian DBD di Indonesia tercatat pada tahun 2010, memiliki jumlah tertinggi di antara negara-negara ASEAN dengan total 156.086 kasus, dengan 1.358 kematian karena penyakit ini. Pada tahun 2011 jumlah kasus menurun menjadi 49.486 namun pada 2012 meningkat menjadi 65.725 kasus (Martini et al, 2019). Pada tahun 2015 jumlah penderita DBD yang dilaporkan sebanyak 129.650 kasus dengan jumlah kematian sebanyak 1.071 orang (Arfan et al, 2019).

Banyaknya kasus yang terjadi di Indonesia, membuat pemerintah melakukan pengendalian vector dengue salah satunya menggunakan insektisida. Abate (temephos) adalah salah satu insektisida yang digunakan untuk mengendalikan serangga pada stadium larva. Penggunaan bahan kimia sebagai larvasida menimbulkan permasalahan tersendiri diantaranya adalah resistensi, pencemaran lingkungan, dan sisa bahan kimia (residu) (Martini et al, 2019; Pineda et al, 2019). Penggunaan bahan alam sebagai larvasida Aedes aegypti bisa menjadi salah satu solusi atas permasalahan yang ada (Maheswaran and Ignacimuthu, 2012). Kajian terkait senyawa bahan alam yang mengandung senyawa alkaloid (Borrero et al, 2018; Masi et al, 2017), saponin (Pelah et al, 2002), flavonoid (Pessoa et al, 2018), tannin (Rey et al, 2000), triterpenoid (Tarmadi et al, 2018), dan polifenol dapat digunakan sebagai agen larvasida (Oulebsir et al, 2018). Penggunaan bahan alam disinyalir dapat mengurangi efek toleransi dan efek samping dibanding bahan kimia (Sasongko et al, 2016).

Bahan alam yang berpotensi sebagai larvasida alami namun di Indonesia belum dimanfaatkan secara optimal adalah bunga melati (Jasminum sambac) dan biji pepaya (Carica papaya L). Bunga melati merupakan salah satu tanaman yang memiliki kandungan alkaloid, karbohidrat, flavonoid, steroid, terpenoid, saponin, tanin, dan senyawa fenolik (Anima et al, 2019; Chen et al, 2018). Diketahui ekstrak etanol bunga melati pada kadar 0,5 0,8\% pemberian dapat membunuh 50\% larva Aedes aegypti (Hidayah, et al,2020). Sementara biji pepaya yang mengandung senyawa asam lemak seperti asam oleat (Mohammad, 2019; Senrayan and Venkatachalam, 2018), senyawa fenolik seperti benzyl isothiocyanate (Hall et al, 2018), saponin, alkaloid, flavonoid dan tanin dapat mempengaruhi aktivitas larvasida (Wahyuni, 2015). Kombinasi dari kedua bahan tersebut diduga memiliki efek yang sinergis. 
Tujuan dari penelitian ini adalah mengidentifikasi aktivitas larvasida formula granul mengandung kombinasi ekstrak bunga melati (Jasminum sambac) dan biji pepaya (Carica papaya $\mathrm{L})$.

\section{Bahan dan Metode}

\subsection{Alat dan bahan}

Bahan yang digunakan dalam penelitian antara lain kuncup bunga melati yang diperoleh dari perkebunan melati kabupeten Tegal, biji buah pepaya yang sudah matang diperoleh dari kota surakarta, n-heksan, alkohol 70\%, kain linen, aluminium foil, laktosa, mucilago gom, dan amilum. Sedangkan alat yang digunakan antara lain gelas beaker, bejana kaca, cawan porselen, rotary evaporator, watterbath, batang pengaduk, corong kaca, baskom, oven, kurs porselin, flowmeter, neraca digital, ayakan no 16 dan 20.

\subsection{Pembuatan simplisia dan ekstraksi}

Bunga melati dipisahkan dari tangkainya dan dibersihkan dengan air kemudian dikeringkan. Biji buah pepaya dipisahkan dari daging buah, dikeringkan dan dilakukan penyerbukan. Ekstraksi bunga melati dilakukan dengan metode maserasi dan n-heksan sebagai pelarut (1:2) selama 12 jam, kemudian diuapkan pada suhu $35^{\circ} \mathrm{C}$ sampai diperoleh concrete. Penyaringan dilakukan 7-8 kali untuk memisahkan lilin yang mengendap. Ekstrak kemudian diuapkan kembali hingga diperoleh ekstrak kental (Benedicta et al, 2016). Biji buah papaya di ekstraksi dengan pelarut etanol 70\% selama 24 jam. Ekstrak etanol biji buah pepaya disaringdan diuapkan menggunakan waterbath hingga didapatkan ekstrak kental (Arimaswati et al, 2017).

\subsection{Penyiapan larva}

Larva yang digunakan adalah larva nyamuk jenis Aedes aegypti. Larva berusia kurang lebih 7-10 hari dari sejak penetasan. Larva disiapkan pada bak pemeliharaan yang berisi aquades steril. Setiap satu bak uji diisi 5 ekor larva.

\subsection{Pembuatan formula}

Granul dibuat dengan metode granulasi basah. Ekstrak bunga melati dan biji pepaya dimasukkan ke dalam wadah yang telah ditimbang kemudian ditambahkan amilum dan laktosa. Campuran ditambahkan mucilago gom dan diaduk hingga terbentuk massa. Massa diayak dengan ayakan mesh no16 hingga terbentuk granul, selanjutnya dikeringkan pada suhu $40^{\mathrm{O}}-50^{\circ} \mathrm{C}$. Granul dihaluskan ukurannya dengan ayakan mesh no.20. Formula granul dibuat ke dalam empat formula dengan variasi dosis terlihat pada (Tabel 1).

\subsection{Uji Sifat Fisik Granul}

\subsubsection{Kadar air}


Sebanyak 400 mg granul ditimbang dan di masukkan ke dalam wadah porselin kering. Wadah dipanaskan dalam oven dengan suhu $105^{\circ} \mathrm{C}$ selama 1 jam dan di dinginkan dalam desikator, kemudian ditimbang.

Tabel 1. Formulasi granul abate dengan variasi dosis kombinasi ekstrak bunga melati dan biji papaya. Keterangan: $q s=$ quantum satis (secukupnya)

\begin{tabular}{lllll}
\hline Bahan & Formula 1 & Formula 2 & Formula 3 & Formula 4 \\
\hline Ekstrak Bunga Melati & $10 \%$ & - & $5 \%$ & $10 \%$ \\
Ekstrak Biji Pepaya & - & $10 \%$ & $5 \%$ & $10 \%$ \\
Amilum Manihot & $2 \%$ & $2 \%$ & $2 \%$ & $2 \%$ \\
Mucilago Gom & qs & qs & qs & qs \\
Laktosa & Ad 10 gram & Ad 10 gram & Ad 10 gram & Ad 10 gram \\
\hline
\end{tabular}

\subsubsection{Kecepatan alir}

Uji kecepatan alir merujuk dari penelitian Rohmani and Rosyanti (2019), yang dimodifikasi dimana sebanyak $10 \mathrm{~g}$ granul dialirkan ke dalam Flowmeter dan dicatat waktu alirnya. Waktu yang dibutuhkan masa granul melewati Flowmeter hingga habis dihitung sebagai daya alir granul.

\subsubsection{Sudut istirahat}

Sejumlah 10 g granul dimasukkan kedalam corong hingga terjatuh membentuk kerucut. Tinggi dan diameter kerucut yang terbentuk dari corong diukur sebagai sudut istirahat.

\subsubsection{Waktu terdispersi}

Sejumlah $400 \mathrm{mg}$ granul dituang kedalam wadah gelas berisi satu liter air dan diaduk sampai terdispersi sempurna. Waktu yang dibutuhkan granul sampai terdispersi dihitung sebagai waktu dispersi.

\subsection{Uji aktivitas larvasida}

Uji larvasida ekstrak bunga melati (EBM) dan ekstrak biji papaya (EBP) menggunakan 30 larva yang terbagi dalam 6 kelompok. Kelompok terbagi pada K1 adalah kontrol negatif yaitu formula granul tanpa zat aktif, K2 kontrol positif (abate), K3 formula mengandung $\mathrm{EBM} 10 \%, \mathrm{~K} 4$ formula mengandung EBP 10\%, K5 formula mengandung kombinasi EBM dan EBP (5\%:5\%) dan K6 formula mengandung kombinasi EBM dan EBP (10\%:10\%). Sebelum dilakukan eksperimen, terlebih dahulu dilakukan seleksi larva yang sehat dan tidak cacat serta dikarantina. Percobaan dilakukan dengan mencampurkan formula ke dalam wadah eksperimen yang berisi larva dalam aquades $50 \mathrm{ml}$. Mortalitas larva diamati selama 24 jam setelah pemberian sampel uji.

\subsection{Analisis data}

Data kematian larva yang terkumpul dihitung nilai persen mortalitasnya dan dianalisis statistik. Uji statistik one way-ANOVA dilanjutkan Post Hoc Test LSD dilakukan untuk 
melihat perbedaan antar kelompok $(\mathrm{p}<0,05)$. Angka persen (\%) mortalitas diukur menggunkan rumus : \% mortalitas $=[($ Jumlah larva awal - Jumlah larva yang masih hidup $) /$ Jumlah larva awal] x $100 \%$.

\section{Hasil dan Pembahasan}

Pembuatan sediaan serbuk granul menggunakan metode granulasi basah dengan tujuan untuk meningkatkan kohesifitas (Soete et al, 2013), dan kompaktibilitas serbuk (Wikberg and Alderborn, 1991) dan kecepatan pelarutan obat (Badawy et al, 2019; Mutch et al, 2019). Hasil pengujian sifat fisik granul dapat dilihat pada Tabel 2 .

Tabel 2. Sifat fisik empat variasi formula granul abate dengan dosis kombinasi ekstrak bunga melati dan biji papaya.

\begin{tabular}{ccccc}
\hline Formula & Kadar Air (\%) & $\begin{array}{c}\text { Waktu Alir } \\
\text { (detik) }\end{array}$ & $\begin{array}{c}\text { Sudut Diam } \\
(\mathbf{o})\end{array}$ & $\begin{array}{c}\text { Waktu Terdispersi } \\
\text { (detik) }\end{array}$ \\
\hline Formula 1 & $3,6 \pm 0,16$ & $3,25 \pm 0,01$ & $27,8 \pm 1,32$ & $22,3 \pm 0,08$ \\
Formula 2 & $2,5 \pm 0,31$ & $3,20 \pm 0,32$ & $28,4 \pm 1,09$ & $22 \pm 1,63$ \\
Formula 3 & $3,5 \pm 0,43$ & $3,30 \pm 0,03$ & $22,7 \pm 1,28$ & $4,78 \pm 0,28$ \\
Formula 4 & $2,8 \pm 0,61$ & $3,10 \pm 0,02$ & $28,6 \pm 1,18$ & $19 \pm 0,81$ \\
\hline
\end{tabular}

Pada uji kadar air Formula 1-4 masih direntang 2-4 \% menurut Lachman dkk (1994), sehingga ke empat formula masih memenuhi persyaratan berdasar literatur. Granul yang baik harus ada kandungan air tertentu karena jika terlalu kering akan membuat granul mudah hancur dan jika terlalu basah sifat alir kurang baik serta akan mudah ditumbuhi jamur terutama mudah terdekomposisi. Ini membuktikan bahwa penggunaan ekstrak bunga melati dan ekstrak biji pepaya dalam formulasi tidak memberikan peningkatan kelembaban yang tinggi, sehingga dalam penyimpanan dapat mempertahankan kondisi kering. Pada waktu alir, bahan pelicin dapat memperbaiki efektivitas kecepatan alir granul (Voigt, 1984). Keseragaman ukuran dan bentuk granul berpengaruh terhadap sifat alir (Lachman, 1994). Granul dengan kecepatan alir lebih dari 10 g/detik mempunyai sifat fisik yang baik (Siregar and Wikarsa, 2010). Hasil pengujian menunjukkan kecepatan alir masih lebih besar dari 10 g/detik. Sudut maksimum yang dibentuk permukaan granul dengan bidang horizontal disebut sebagai sudut diam. Granul dengan sudut diam yang kecil menghasilkan sifat fisik yang baik karena granul dapat mengalir dengan bebas. Ukuran sudut diam yang baik adalah $\leq 30^{\circ}$ (Lachman dkk, 1994). Tabel 2 menunjukkan keempat formula memiliki sudut diam $\leq 30^{\circ}$ sehingga keempat formula mempunyai daya alir yang baik. Kecepatan granul terdispersi dilakukan dengan cara memasukkan granul kedalam air sebagai medium dispers. Granul terdispersi sempurna dalam waktu $<5$ menit menunjukkan sifat fisik yang baik (Siregar dan Wikarsa, 2010). Pada evaluasi waktu terdispersi, diketahui bahwa keempat formula 
memenuhi standar waktu larut yakni kurang dari 5 menit. Waktu dispersi berhubungan dengan kecepatan pelepasan obat pada media uji (Gao et al, 2019). Akan tetapi kecepatan dispersi tidak selalu berkorelasi dengan efek dari suatu obat karena masih banyak faktor lain diantaranya adalah sifat zat aktif dan ukuran partikelnya (Szafraniec et al, 2019). Hasil pengujian aktivitas larvasida dapat dilihat pada tabel 3.

Tabel 3. Nilai persentase mortalitas dari setiap kelompok perlakuan. Tanda asterisk $(*)$ menunjukkan perbedaan yang signifikan $(\mathrm{p}<0,05)$ bila dibandingkan dengan kontrol negative.

\begin{tabular}{lccc}
\hline Kelompok & $\begin{array}{c}\text { Jumlah Larva } \\
\text { awal }\end{array}$ & $\begin{array}{c}\text { Jumlah rata - } \\
\text { rata } \text { mortal }\end{array}$ & Persen (\%) mortalitas \\
\hline Kontrol Negatif & 5 & 0 & $0 \%$ \\
Kontrol Positif & 5 & 5 & $100 \%$ \\
Formula 1 & 5 & 0 & $0 \%$ \\
Formula 2 & 5 & 3 & $60 \% *$ \\
Formula 3 & 5 & 0,67 & $13,4 \% *$ \\
Formula 4 & 5 & 1,33 & $26,6 \% *$ \\
\hline
\end{tabular}

Pada tabel 3 diketahui bahwa kelompok kontrol positif yaitu serbuk abate menghasilkan nilai persen mortalitas larva sebesar $100 \%$. Hal ini sesuai dengan fungsi utamanya bahwa serbuk abate diproduksi dan sudah sering digunakan oleh banyak negara untuk melakukan pengengendalian jentik nyamuk (Melo et al, 2010; Vasantha et al, 2017). Abate bekerja dengan menghambat enzim vital untuk fungsi normal pada sistem saraf larva (Pope, 1999). Toksisitas relatif aman untuk manusia setelah diencerkan pada air, namun penggunaan jangka panjang dapat menyebabkan kejadian resistensi pada larva nyamuk sehingga larva menjadi kebal terhadap abate (Grigoraki et al, 2016; Melo et al, 2010). Pada kontrol negatif terlihat tidak ada kematian larva, sehingga hal tersebut menunjukkan bahwa formula granul yang tidak mengandung zat aktif tidak mempunyai kemampuan sebagai larvasida.

Kelompok perlakuan ekstrak bunga melati dan biji pepaya pada perbandingan 5\%:5\% dan 10\%:10\% menghasilkan kematian larva sebesar 13,4\% dan 26,6\%. Nilai ini lebih rendah dari formula yang mengandung ekstrak tunggal biji papaya yaitu 60\%. Pada kelompok yang diberikan ekstrak tunggal bunga melati tidak menghasilkan persen mortalitas. Hal ini bisa dimungkinkan karena senyawa yang berperan sebagai larvasida dalam ekstrak tunggal bunga melati masih dibawah dosis toksik terhadap larva. Dosis yang tidak mencapai kadar minimal efek toksik dalam jendela terapi tidak bisa memberikan efek ketoksikan (Malhotra and Perry, 2003). Kombinasi suatu bahan obat tidak selalu menghasilkan efek sinergis. Kombinasi dari suatu bahan obat bisa saling meniadakan terhadap efeknya atau sering disebut dengan efek antagonis (Bartoňková and Dvořák, 2018; Foucquier and Guedj, 2015).

Ekstrak biji papaya mempunyai efek mortalitas terhadap larva disebabkan karena 
kandungan saponin, flavonoid dan triterpenoid (Wahyuni, 2015). Flavonoid menurunkan rasa ingin makan larva sehingga kebutuhan nutrisi tidak terpenuhi yang mengakibatkan kematian larva (Tiwary et al, 2007). Saponin bersifat toxic dan mengakibatkan hemolysis dalam pembuluh darah larva. Selain itu, penghambatan metamorfosis dan pembentukan kulit larva oleh saponin menjadi penyebab kematian larva (Sarwar et al, 2009). Triterpenoid adalah senyawa toksik akut dan bisa meningkatkan kematian pada larva (Wahyuni, 2015). Selain saponin, flavonoid, dan triterpenoid, biji buah papaya juga mengandung tegupain. Tegupain merupakan sistein proteinase dimana enzim tegupain secara efisien menghidrolisis substrat $Z$ Phe-Arg-pNan. Tegupain bertanggung jawab atas pembentukan senyawa beracun yang ada di kotiledon Carica pepaya melawan Aedes aegypti (Nunes et al, 2013).

\section{Kesimpulan}

Hasil penelitian menunjukkan bahwa formula yang mengandung ekstrak tunggal EBP memberikan nilai persen mortalitas yang paling signifikan $(\mathrm{p}<0,05)$ dengan nilai $60 \%$. Pada formula kombinasi $\mathrm{EBM}$ dan $\operatorname{EBP}(5 \%: 5 \%$ dan 10\%:10\%) memberikan nilai persen mortalitas sebesar $13,4 \%$ dan $26,6 \%$. Hal ini membuktikan bahwa kombinasi ekstrak tidak selalu memberikan efek yang lebih baik (efek sinergis) dibandingkan dengan sediaan tunggalnya.

\section{Ucapan Terimakasih}

Terimakasih penulis sampaikan kepada BELMAWA RISTEKDIKTI atas pendanaan penelitian melalui skema PKM-PE tahun 2019 dan Universitas Sebelas Maret atas bantuan fasilitas penelitian.

\section{Deklarasi Konflik Kepentingan}

Semua penulis menyatakan tidak ada konflik kepentingan terhadap naskah ini.

\section{Daftar Pustaka}

Anima, P., Arun, M., Satish, S. (2019). Scientific validation of wound healing potential of Jasminum sambac Ait. South African Journal of Botany, 121:584-589.

Arfan, I., Saleh, I., Cambodiana, M. (2019). Keberadaan Jentik Aedes Sp Berdasarkan Karakteristik Kontainer di Daerah Endemis dan Non Endemis Demam Berdarah Dengue. Jurnal Ilmiah Ilmu Kesehatan: Wawasan Kesehatan, 5: 258-266.

Arimaswati, A., Sawaluddin, L.O.M., Sudrajat, H.W. (2017). Efek Larvasida Ekstrak Biji Buah Pepaya (Carica papaya L.) terhadap Larva Instar III Aedes aegypti L. Medula, 4.

Badawy, S.I.F., Narang, A.S., LaMarche, K.R., Subramanian, G.A., Varia, S.A. (2019). Chapter 3 - Mechanistic Basis for the Effects of Process Parameters on Quality Attributes in High Shear Wet Granulation, in: Narang, A.S., Badawy, S.I.F. (Eds.). Handbook of Pharmaceutical Wet Granulation. Academic Press, pp. 89-118. 
Bartoňková, I., Dvořák, Z. (2018). Essential oils of culinary herbs and spices display agonist and antagonist activities at human aryl hydrocarbon receptor AhR. Food and Chemical Toxicology, 111: 374-384.

Benedicta, N.O., Zain, S., Nurjanah, S., Widyasanti, A., Putri, S.H. (2016). Pengaruh Rasio Bunga dengan Pelarut Terhadap Rendemen dan Mutu Minyak Melati (Jasminum Sambac) Menggunakan Metode Ekstraksi Pelarut Menguap (Solvent Extraction). Teknotan: Jurnal Industri Teknologi Pertanian, 10.

Borrero Landazabal, M.A., Carreño Otero, A.L., Kouznetsov, V.V., Duque Luna, J.E., Mendez-Sanchez, S.C. (2018). Alterations of mitochondrial electron transport chain and oxidative stress induced by alkaloid-like $\alpha$-aminonitriles on Aedes aegypti larvae. Pesticide Biochemistry and Physiology, 144: 64-70.

Chen, G.-L., Chen, S.-G., Xiao, Y., Fu, N.-L. (2018). Antioxidant capacities and total phenolic contents of 30 flowers. Industrial Crops and Products, 111: 430-445.

Foucquier, J., Guedj, M. (2015). Analysis of drug combinations: current methodological landscape. Pharmacology Research and Perspective, 3.

Gao, Z., Ngo, C., Ye, W., Rodriguez, J.D., Keire, D., Sun, D., Wen, H., Jiang, W. (2019). Effects of Dissolution Medium $\mathrm{pH}$ and Simulated Gastrointestinal Contraction on Drug Release From Nifedipine Extended-Release Tablets. Journal of Pharmaceutical Science, 108: 1189-1194.

Grigoraki, L., Balabanidou, V., Meristoudis, C., Miridakis, A., Ranson, H., Swevers, L., Vontas, J. (2016). Functional and immunohistochemical characterization of CCEae3a, a carboxylesterase associated with temephos resistance in the major arbovirus vectors Aedes aegypti and Ae. albopictus. Insect Biochemisstry and Molecular Biology, 74: 61-67.

Hall, R.M., Mayer, D.A., Mazzutti, S., Ferreira, S.R.S. (2018). Simulating large scale SFE applied to recover bioactive compounds from papaya seeds. The Journal of Supercritical Fluids, 140: 302-309.

Hidayah, N., Suhartono, E., Hakim, A.R. and Ramadhan, A.R.R. (2020). Bio-larvicidal effectiveness of Jasminum sambac (L.) ait (Oleaceae) and Stenochlaena palustris (Blechnaceae) against dengue vector, Aedes aegypti (Linn.) (Diptera: Culicidae). Eurasian Journal of Biosciences, 14 (2): 7205-7210.

Ikawati, B. (2018). Aspek Kekinian tentang Penelitian Demam Berdarah Dengue di Pulau Jawa dan Sekitarnya. Balaba: Jurnal Litbang Pengendalian Penyakit Bersumber Binatang Banjarnegara, 85-94.

Lachman,L.,Liberman, H.A., Karrig, J.L. (1994). Teori dan Praktek Farmasi Industri, diterjemahkan oleh Siti Suyatmi, jilid 2, Edisi III, 1031-1032, 1034, 1053, 1057, 1091, Penerbit UI: Jakarta.

Maheswaran, R., Ignacimuthu, S. (2012). A novel herbal formulation against dengue vector mosquitoes Aedes aegypti and Aedes albopictus. Parasitology Research, 110:18011813.

Malhotra, V., Perry, M.C. (2003). Classical Chemotherapy: Mechanisms, Toxicities and the Therapeutc Window. Cancer Biology and Therapy, 2: 1-3. 
Martini, M., Hestiningsih, R., Widjanarko, B., Purwantisasari, S. (2019). Resistance of Aedes as a Vectors Potential for Dengue Hemorrhagic Fever (DHF) in Semarang City, Indonesia. Journal of Tropical Life Science, 9: 89-94.

Masi, M., van der Westhuyzen, A.E., Tabanca, N., Evidente, M., Cimmino, A., Green, I.R., Bernier, U.R., Becnel, J.J., Bloomquist, J.R., van Otterlo, W.A.L., Evidente, A. (2017). Sarniensine, a mesembrine-type alkaloid isolated from Nerine sarniensis, an indigenous South African Amaryllidaceae, with larvicidal and adulticidal activities against Aedes aegypti. Fitoterapia, 116: 34-38.

Melo-Santos, M.A.V., Varjal-Melo, J.J.M., Araújo, A.P., Gomes, T.C.S., Paiva, M.H.S., Regis, L.N., Furtado, A.F., Magalhaes, T., Macoris, M.L.G., Andrighetti, M.T.M., Ayres, C.F.J. (2010). Resistance to the organophosphate temephos: Mechanisms, evolution and reversion in an Aedes aegypti laboratory strain from Brazil. Acta Tropica, 113: 180-189.

Mohammad, I. (2019). Gold nanoparticles: An efficient carrier for MCP I of Carica papaya seeds extract as an innovative male contraceptive in albino rats. Journal of Drug Delivery Science and Technology, 52: 942-956.

Mutch, G.A., Hapgood, K.P., Shen, R., Selomulya, C. (2019). An investigation on the dissolution qualities of foam granulated products. Powder Technology, 343: 693-704.

Nunes, N.N. dos S., Santana, L.A., Sampaio, M.U., Lemos, F.J.A., Oliva, M.L. (2013). The component of Carica papaya seed toxic to A. aegypti and the identification of tegupain, the enzyme that generates it. Chemosphere,92: 413-420.

Oulebsir-Mohandkaci, H., Baba Aissa, A., Badaoui, S., Bouyahiaoui, H., Ait Kaki, S., Mohammedi, A. (2018). Comparative study of the toxicity of phenolic compounds of coriander (Coriandrum sativum) and false fennel (Aneth graveolens) on Galleria mellonella (Lepidoptera, Pyralidae). Euro-Mediterranean Journal of Environmental Integration, 3: 1-7.

Pelah, D., Abramovich, Z., Markus, A., Wiesman, Z. (2002). The use of commercial saponin from Quillaja saponaria bark as a natural larvicidal agent against Aedes aegypti and Culex pipiens. Journal of Ethnopharmacology, 81: 407-409.

Pessoa, L.Z. da S., Duarte, J.L., Ferreira, R.M. dos A., Oliveira, A.E.M. de F.M., Cruz, R.A.S., Faustino, S.M.M., Carvalho, J.C.T., Fernandes, C.P., Souto, R.N.P., Araújo, R.S. (2018). Nanosuspension of quercetin: preparation, characterization and effects against Aedes aegypti larvae. Revista Brasileira de Farmacognosia, 28: 618-625.

Pineda-Cortel, M.R.B., Cabantog, R.J.R., Caasi, P.M., Ching, C.A.D., Perez, J.B.S., Godisan, P.G.M., Latorre, C.M.G., Lucero, D.R., Salonga, R.B. (2019). Larvicidal and ovicidal activities of Artocarpus blancoi extracts against Aedes aegypti. Pharmaceutical Biology, 57: 120-124.

Pope, C.N. (1999). Organophosphorus Pesticides: Do They All Have the Same Mechanism of Toxicity? Journal of Toxicology and Environmental Health Part B, 2: 161-181.

Rey, D., David, J.-P., Martins, D., Pautou, M.-P., Long, A., Marigo, G., Meyran, J.-C. (2000). Role of vegetable tannins in habitat selection among mosquito communities from the 
Alpine hydrosystems. Comptes Rendus de I'Académie des Sciences- Ser. III, 323: 391398.

Rohmani, S. and Rosyanti, H. (2019). Perbedaan metode penambahan bahan penghancur secara intragranular-ekstragranular terhadap sifat fisik serta profil disolusi tablet ibuprofen. JPSCR: Journal of Pharmaceutical Science and Clinical Research, 4(2): 95-108.

Sarwar, M., Ahmad, N., Toufiq, M. (2009). Host plant resistance relationshiphs in chickpea (cicer arietinum 1.) against gram pod borer (helicoverpa armigera hubner. Pak. J. Bot. 41, 3047-3052.

Sasongko, H., Sugiyarto, S., Efendi, N.R., Pratiwi, D., Setyawan, A.D. and Widiyani, T., 2016. Analgesic Activity of Ethanolic Extracts of Karika Leaves (Carica pubescens) In Vivo. JPSCR: Journal of Pharmaceutical Science and Clinical Research, 1(2), pp.8389.

Senrayan, J., Venkatachalam, S., 2018. Solvent-assisted extraction of oil from papaya (Carica papaya L.) seeds: evaluation of its physiochemical properties and fatty-acid composition. Sep. Sci. Technol. 53, 2852-2859.

Siregar, C.J.P. and Wikarsa S. 2010. Teknologi Farmasi Sediaan Tablet : Dasar-dasar Praktis. Jakarta : EGC

Soete, W.D., Dewulf, J., Cappuyns, P., Vorst, G.V. der, Heirman, B., Aelterman, W., Schoeters, K., Langenhove, H.V., 2013. Exergetic sustainability assessment of batch versus continuous wet granulation based pharmaceutical tablet manufacturing: a cohesive analysis at three different levels. Green Chem. 15, 3039-3048.

Szafraniec, J., Antosik, A., Knapik-Kowalczuk, J., Chmiel, K., Kurek, M., Gawlak, K., Odrobińska, J., Paluch, M., Jachowicz, R., 2019. The Self-Assembly Phenomenon of Poloxamers and Its Effect on the Dissolution of a Poorly Soluble Drug from Solid Dispersions Obtained by Solvent Methods. Pharmaceutics 11, 130.

Tarmadi, D., Gunandini, D.J., Yusuf, S., 2018. Larvicidal Activity of Cerbera odollam Gaertn Against a Dengue Vector, Aedes aegypti (Diptera: Culicidae), in: McLellan, B. (Ed.), Sustainable Future for Human Security: Environment and Resources. Springer Singapore, Singapore, pp. 175-188.

Tiwary, M., Naik, S.N., Tewary, D.K., Mittal, P.K., Yadav, S., 2007. Chemical composition and larvicidal activities of the essential oil of Zanthoxylum armatum DC (Rutaceae) against three mosquito vectors. J. Vector Borne Dis. 44, 198-204.

Vasantha-Srinivasan, P., Senthil-Nathan, S., Ponsankar, A., Thanigaivel, A., Edwin, E.-S., Selin-Rani, S., Chellappandian, M., Pradeepa, V., Lija-Escaline, J., Kalaivani, K., Hunter, W.B., Duraipandiyan, V., Al-Dhabi, N.A., 2017. Comparative analysis of mosquito (Diptera: Culicidae: Aedes aegypti Liston) responses to the insecticide Temephos and plant derived essential oil derived from Piper betle L. Ecotoxicol. Environ. Saf. 139, 439-446.

Voigt. 1984. Buku Ajar Teknologi Farmasi. Diterjemahkan oleh Soendani Noeroto S.,UGM Press, Yogyakarta. Hal: 337-338. 
Wahyuni, D., 2015. New Bioinsecticide Granules Toxin from Ectract of Papaya (Carica Papaya) Seed and Leaf Modified Against Aedes Aegypti Larvae. Procedia Environ. Sci., Basic Researches in The Tropical and Coastal Region Eco Developments 23, 323-328.

Wikberg, M., Alderborn, G., 1991. Compression characteristics of granulated materials. IV. The effect of granule porosity on the fragmentation propensity and the compatibility of some granulations. Int. J. Pharm. 69, 239-253.

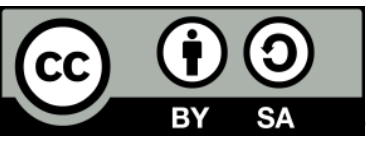

C 2021 by the authors. Submitted for possible open access publication under the terms and conditions of the Creative Commons Attribution-ShareAlike 4.0 International (CC BY-SA 4.0) license (https://creativecommons.org/licenses/by-sa/4.0/). 